\title{
VERSITA
}

\section{The European Union in the Estonian Public Discourse}

\author{
Katri Vaaks \\ Institute of International Relations Prague \\ Nerudova 3, \\ Prague 11850, Czech Republic \\ E-mail: katri.vaaks@gmail.com
}

\begin{abstract}
Debates about the democratic legitimacy of the European Union (EU) have been prevalent amongst scholars since its beginning. Students have analysed the legitimacy of the EU in terms of various normative criteria. But how is the EU legitimated in individual Member States and more so in an economic and sovereignty crisis when loyalties are particularly tested? The current study sheds light on it, scrutinising the conceptions associated with the EU in a country case of Estonia. Discourse analysis is used as a methodological tool to analyse the political discourse in printed media. The results indicate that the legitimation of the EU is derived from its output-oriented strategies, seeing the EU largely in instrumental terms.
\end{abstract}

Keywords: discourse analysis, Estonia, European Union, EU legitimacy

\section{Introduction}

There is nothing new in that the EU is confronting multiple crises: not only the democratic and legitimacy crisis (Eriksen \& Fossum, 2000; Dobson \& Weale, 2003; Føllesdal \& Hix, 2006; Wimmel, 2009) but the deep financial and debt crisis which only highlights the pre-existing crisis of legitimacy in the EU (Marquand, 2011). It has been claimed that the EU seems to lack its legitimation mechanisms, is thus not legitimised in its own right (Menon \& Weatherill, 2008) or lacks a legitimising 'grand narrative' (Schmidt, 2010). Within this contradictory legitimacy debate, some authors claim that it is sufficient to derive legitimacy from its output strategies (Majone, 2006), others claim that shared identity in a form of homogeneous national community-demos-is a 
necessary element of democratic legitimacy (Eriksen \& Fossum, 2004; Cerutti, 2008).

In order to resolve the legitimacy problems, scholars have suggested various potential solutions by distinguishing certain categories to cover all possible dimensions of EU legitimacy (Eriksen \& Fossum, 2004; Lord \& Magnette, 2004; Føllesdal, 2006; Sjursen, 2002; 2008; Schmidt, 2010). For instance, Sjursen $(2002 ; 2008$, pp. 4-6) proposes three mutually exclusive discourses about the EU which includes the EU as a problem-solving entity, value-based community and a rights-based union based on visions of European integration.

Although these theoretical debates provide some understanding on European unity, less is written about small nation states. After all, given there are 27 Member States, Nicolaïdis and Lacroix (2010, p. 409) argue that each nation state offers its own narrative about the EU as to what the EU should be and do internally and externally. In this regard, Braun (2008; 2009) proposes four different rationalisations on legitimacy that are derived from the analysis of two small Member States, the Czech Republic and Sweden, where the EU is seen as an instrument, artificial hindrance and natural entity. The analysis reflects how the membership of the EU and the integration processes was advocated before the referendum of each country. According to these four hypotheses, the EU unity can be explained around the concepts of modernisation and sovereignty. Braun $(2008 ; 2009)$ states that the legitimacy of the EU is largely shaped by the domestic discourses on European governance, proposing four hypotheses as to how the EU can be understood:

1. An instrument to achieve the progress and catch up with more developed countries (considers not only economic output but also geopolitical output in terms of security and influence in world affairs);

2. A hindrance as it forces its ideological project to Member States. The policy outcomes might conflict with the interests of the citizens;

3. A natural political unit posing no challenge to the existence of the nation state;

4. An artificial political unit that challenges the state as some sovereignty is given up.

The aim of the current study is to see whether those categories are applicable on another small Member State, such as Estonia. Whilst these hypotheses are taken into account, I am open to any possible interpretations and upcoming concepts specific to the Estonian public discourse. In the Czech discourse, the 
EU is foremost understood as an instrument for modernisation which, given the previous literature and findings, is also plausible in the Estonian discourse on the EU unity. In the field of European integration studies, there is in fact already a large body of work on the European discourse in Estonia, including the EU construction in the printed media (Raudsaar, 1995; Talts \& Kirch, 1998; Talts, 2000; Raik, 2000), public discussion and opinion (Kirch et al., 1998; 2002; Ruutsoo \& Kirch, 1998; Kirch, 2002; 2007; Vetik, 2001; 2003) or attitudes towards the EU on individual level (Runnel, 2003). However, it would be fruitful to find out how the EU is perceived at times of crisis when loyalties become contested. The study contributes to the understanding of European discourse on European unity and legitimating mechanisms of the state-like structure testing it on small Member States with a specific geopolitical position where security has played an important role in national discourse.

The paper starts off by presenting a theoretical section including the sources of legitimacy, an overview of Estonia's membership in the EU. Secondly, the reasons for using a discourse analysis are outlined. Thirdly, the study analyses the results in the framework of legitimacy debate. The study is set in a period of economic recession which started in 2007 in which the author of the paper concentrates on recurring conceptualisations of the EU in printed media using a discourse analyses. The time-frame of the selected articles is two years from June 2010 to July 2012. Estonia adopted the euro in January 2011 and during this year various key events took place, such as the Portuguese bailout in May, the second Greek bailout in October, the Stability and Growth Pact that came into force in December 2011, and discussions of the adoption of the European Stabilisation Mechanism (ESM).

\section{Theoretical framework}

\subsection{Some conceptualisations on legitimacy}

It is widely agreed that legitimacy is a highly contested concept. In this study legitimacy is defined as 'a recognition of the right to govern' (Coicaud, 2002, p. 10). Most of the existing studies on the EU legitimacy debate provide certain categories for assessment of legitimacy and suggest the modes for governance in the framework of normative theory. Scharpf (1999) proposed to differentiate between two broad concepts of democracy legitimate of a political order-input and output legitimacy. Output legitimacy arguments emphasise 'government for the people' and refer to the government's capacity to solve problems and promote common welfare. In this sense, a range of common interests are 
required to reach the collective solutions (Scharpf, 1999, p. 6). Input legitimacy arguments emphasise 'government by the people' where legitimacy is derived from citizens' equal participation in decision making; however, preconditions such as collective identity and a European demos, which the EU seems to lack, are necessary (Scharpf, 1999, p. 6).

Both categories are hotly debated by scholars. Eriksen and Fossum (2004) assure that output legitimacy is not sufficient as the cooperation between the Member States might become unstable. In addition, solely the benefits provided by the EU may not guarantee the cooperation. The interests of the Member States may decrease once the benefits have been gained. In a similar vein, Cerutti (2008) claims that outcomes also require certain values and principles to guide the performance that make the performance valued, thus referring to Weberian legitimacy. However, it is also likely that the ongoing economic crisis diminishes the credibility of the output-oriented legitimacy of the EU. The EU's traditional reliance on output legitimacy now has become more questionable, as the EU and national governments have failed to deliver economic growth (Schwarzer \& Youngs, 2013). Next, the paper outlines briefly the most important aspects of the short history of Estonia in regard of the EU.

\section{Estonia in the European Union}

Since 1991, the government of Estonia has demonstrated its interest in joining the EU as one of its foreign policy goals. It has expressed consistent support towards the unity of the EU and even more so during the economic crisis which started in 2007 by adopting the euro on January $1^{\text {st }}, 2011$ and taking harsh austerity measures, thus remaining a model EU nation in the midst of a crisis. Estonia was also one of the countries that kept supporting the Constitutional Treaty when other Member States such as France and Netherland voted 'no'.

After the collapse of the communist regime, Estonia amongst the rest of the previous Soviet bloc has been revising its national identity and postulating new identities. Estonian elite, academics and intellectuals have declared the country's 'return to Europe', as Estonian Foreign Minister Toomas Hendrik Ilves (1999) put it: "Integrating into the EU represents the culmination of Estonian road back to Europe and Estonia's road forward to its rightful place as a wellfunctioning, modern nation state". Thus, membership in the EU is viewed as proof of Estonia's European character (Kuus, 2002a). 
Joining the EU has been a strategic step in Estonia's recent history as it was quickly acknowledged that being left out of the Eastward Enlargement processes would have had fatal impact on Estonia (Ruutsoo, 1998). The most prevalent argument for the EU membership in the elite's rhetoric of Estonia was re-gaining the state's rightful place in Europe. After all, according to prevalent opinion of the Estonian scholars, even though Estonia can be regarded as a borderland by the neighbouring Russia, it is seen as firmly belonging, historically and integrally, to the West, in Hungtington's terms to Lutheran-German civilisation (Ruutsoo, 1995). Thus, being included in the first round of accession negations in 1997 with other Eastern and European countries was euphorically welcomed by Estonians and was considered an important milestone in forming a new identity, demonstrating that Estonia is and has been integrally part of Europe (Ruutsoo, 1998). As Drulak (2001) notes, European identity was largely characteristic in the debates to the applicant countries back then. Firstly, the end of the communist regime put the collective identities of people into question in Central and Eastern Europe. Secondly, the states had both economy- and security-wise little if anything to contribute, rather than the other way around (Drulak, 2001).

Indeed, the main rationales behind the efforts of joining the EU were Estonia's peripheral location, gaining political stability as well as economic credibility in the eyes of the West, and catching up with global processes of modernisation (Kirch \& Kirch, 2001). The keywords for modernisation such as 'harmonisation', 'catching up' and 'adaptation' could be distinguished at that time (Vetik, 2003, p. 265). Considering Estonia's geopolitical position as a neighbour to Russia, the EU was also conceived as an additional security guarantee (Kirch \& Talts, 2000; Ruutsoo et al., 1998). The membership of the EU was additionally pursued for securing the preservation of Estonia's national identity, culture and independence under the increasing pressure of globalisation (Palk, 1999). Although Estonia's expectations for security guarantees in the process of the accession to the EU were undoubtedly more clearly defined than its stands regarding identity (Kirch et al., 2002), both security and identity were prioritised over the anticipated economic benefits of the integration process according to Kuus (2002b). It is worth noting that the sovereignty in Estonia can be characterised by a close linkage of the security of the national identity that can be compared with a Westphalian sovereignty concept in which the territorial state is a central object for a natural expression of a nation (Rasmussen, 2004).

Estonia joined the EU in May 2004, after a referendum in 2003 by 66.83 per cent of voters supporting membership. However, primarily national interests characterised Estonia's EU policy in 2003-2004 under the government led by the conservative party Res Publica. Despite a broad elite consensus on EU 
membership, some parliamentary political parties occasionally demonstrated their Eurosceptic attitudes or expressed reserved attitudes towards Estonia's interest in joining 'yet another' union (Ehin, 2006) and losing part of its sovereignty (Kirch et al., 2002). The free market Reform Party was partly fissured by a belief that the EU is over-regulated and bureaucratic, and that joining it would cause a slowdown in Estonian economic growth. The Eurosceptic Centre Party claimed that the government was too compliant towards EU demands.

Public opinion has altered over time since the initial formal EU discussions. The first phase can be characterised by euphoric voices even though the EU was still perceived a distant entity. After 1995, the enthusiasm declined and was replaced by the intellectual Euroscepticism in 2001-2002 (Kirch, 2002; 2007). Nevertheless, before the referendum in 2003 the support towards the EU increased, which amongst other things can be associated with the citizens' expectations for economic welfare (Kirch, 2007). In the following years, Euroscepticism was replaced with a higher percentage of positive tones with the trust in the EU reaching 61 per cent in 2010 (Eurobarometer, 2011).

\section{Discourse Analysis}

Discourse Analysis (DA) is employed in a range of research approaches that focus on the use of language and the popularity of it in academic research. The approach of DA has been previously used by various scholars in integration and identity studies (Diez, 2001; Olausson, 2010).

Traditions of Discourse Analysis are grounded on a variety of social theories, such as those of Laclau, Mouffe, Bourdieu and Foucault. Michel Foucault (1972) conceived language as a discourse that not only reflects reality but produces a meaning. Political theorists Laclau and Mouffe extended his ideas in their works and later analysed political life in terms of discourse (Howarth, 1995).

Ole Waever (2004), a leading figure of the Copenhagen school, has stated that "discourse is the layer of reality where meaning is produced and distributed". This paper considers DA as a methodological tool where discourse is utilised as a "system that regulates the formation of statements" (Foucault, 1972). While applying DA the theorists are not interested what things are but how they become meaningful in discourse (Waever, 2004, p. 198).

The author of the current study has chosen a discourse analysis as the most appropriate methodological tool for the current study for various reasons. There 
are numerous categories that are used to construct the EU and they differ from one another. DA is a helpful tool to study layers and meaning in different concepts thus the author considers it a fruitful approach in studying the EU as a contested concept. The data for the study comes from the excerpts of the editorial and opinion articles as well as economic ones in several Estonian newspapers such as Eesti Päevaleht, Postimees, Sirp and Diplomaatia (online issues). It should be noted that the articles written by the parliament members are also included which foremost unequivocally express supportive attitudes towards the EU in the line of its necessity for the Estonia nation state.

\section{Results}

Presenting the EU in instrumental terms is clearly evident in the Estonian discourse. The EU is seen predominantly positively from various aspects such as a positive impact on economic growth and protecting sovereignty. It is presumable, considering the elite's consistent pro-European stance towards the EU and Estonia's geopolitical location in regard of neighbouring Russia. Joining the EU is often referred to as an achievement or even a triumph which cannot be doubted (Hanso, 2011) or a roof that has made the economic development possible.

Structural subsidies and funds provided by the EU stand out in the debate of the Estonian discourse. Metaphorically stated as "a donor blood to a wounded soldier" ('Ansipi majandusime...,' 2012) these allow a country to catch up with the core Member States, increase competitiveness and make the state economically more stable. Distribution of subsidies to the less developed Member States is linked to the concepts of 'commitment and obligation' on the part of the EU. In Estonia's case it is justified by the small size of a country located in the periphery of the $\mathrm{EU}$, thus its weaker position that until today needs measures to stay competitive within the EU. The abovementioned arguments correspond to instrumental hypothesis. The EU as a tool of modernisation and opportunity is contrasted with the threat of being isolated and backward, making even survival questionable and marginalised in terms of economy and trade. However, according to some critical arguments, Estonia does not benefit fully from the subsidies as they have been unequally distributed or ineffectively in some areas, for example agricultural subsidies in Member States. The regulations contain bureaucratic elements which Estonia does not always benefit from. These arguments remain relatively modest and they refer to the EU as hindrance. 
Hence, Estonia is not solely in the role of a passive receiver. Concepts such as rules and norms are stressed in the Estonian discourse. Cooperation (based on solidarity) and responsibility or lack of it are values that emerge in debates. A lack of necessary cooperation and solidarity towards the EU may hinder the progress, and thus can affect Estonian road to progress. More specifically, countries such as Greece, which is not abiding by the rules and acts irresponsibly, is described in negative terms.

The EU distinctively stands out as a unit that ensures national security and defence. In this regard, the membership is viewed as a rational choice which helps to achieve it. This is not surprising as security has been high on the agenda in the Estonian foreign policy since 1991 after restoring the independence. Estonia's geopolitical situation is often emphasised while clarifying a strong pro-European attitude. "'Let the devil catch them': Euroscepticism is not a solution for Estonia. The EU represents a huge surplus value that should be in our case multiplied by a coefficient of Russia. Jumping off the sea we will find ourselves in a wavy water" (Lobjakas, 2011a). The membership can be interpreted as a necessity and unavoidable, otherwise Estonia could end up in isolation. Belonging to the EU avoids in principle belonging to another potentially threatening union, the Soviet Union, which is historically known for its ultimate restriction of Estonia's freedom and sovereignty. These arguments demonstrate that the EU is described in instrumental terms.

Values, such as solidarity, are also linked to the discussions of sovereignty. It is important to stay solidary even at the time of crisis which is driven by Estonia's own interests, amongst economic reasons a necessity in an attempt to guarantee the state's security. Thus, having solidarity can be interpreted as self-interest driven by a strong necessity. However, providing financial support towards the Member States (e.g., Greece) in the eurozone crisis has proved to be challenging if not unjustifiable for a small nation state (Raig \& Selge, 2012).

The EU is viewed positively as an instrument as it gives voice to Estonia, represents Estonia in foreign politics as a negotiator, particularly regarding the relationship with Russia. Thus, membership is interpreted as a tool helping to resolve conflict situations (where Estonia has limited capacities) and add credibility.

Deeper integration including joining the eurozone is another theme that emerges in the Estonian discourse. Both would serve as an instrument in guaranteeing Estonia's economy and security thus clearly corresponding to instrumental hypothesis. Therefore, joining the eurozone is described both as a necessity and 
an unavoidable step. In a larger picture, the survival of the eurozone is equated with a survival of the EU.

Joining the eurozone is not only an economic act but also political. The goal of Estonian foreign policy during the last 17 to 18 years has been to tie it forever to the West Europe. Joining the EU euro currency is one step towards it. (Kaljuvee, 2010)

However, the future of the eurozone and consequences of joining it are not perceived through the rose-coloured glasses. Here the EU appears as a unit which is "in the cycle of changes", has no clear direction due to the economic crisis, and is thus unstable. This results in fears - the collapse of the euro is equated with a collapse of the EU which poses a danger to Estonia. It would lead the state to a geopolitical isolation with no voice in world politics.

Should the eurozone collapse and the EU become paralysed (in a better scenario), we would find ourselves rather alone on the coast of the Baltic Sea: catatonic Latvia in the South, rising Russia in the East, and in the North and in the West the only states in the region with independent defensive potential that are unfortunately interested in us only as markets. (Lobjakas, 2011b)

Regarding the euro crisis, the EU is also referred to as a union which is in coma, stagnant, bureaucratic or not able to make any radical choice. It can either marginalise or remain only an economic union. These concepts are not explicitly debated in direct linkage to Estonia, rather as a general observation in the course of the unfolding economic eurozone crisis. These articulations seem to correspond to the hindrance hypothesis.

The EU is also viewed as a supreme legal entity. For Estonia there are unused opportunities to get actively involved in legal debates of the EU. It particularly manifests in discussions of adopting the ESM which results in crucial amendments in the Estonian Constitution. The Constitution is and should be maintained as it is, as the basis of a sovereign nation state. These articulations accord to the EU as artificial unit, as Constitution-related amendments would mean giving up part of a sovereignty. In these debates Estonia emerges as a passive and obedient follower of the EU while Estonia conceives the EU as a unit representing the supreme law. Estonia should make its voice heard due to its model student status, thus it has 'earned' it (considering its favourable position with low national debt compared to other Member States). In addition, citizens' interests are not considered in the decision-making process of the national elite which seems to lack transparency. In the light of the debates 
regarding the ESM and constitutional changes, the EU is becoming increasingly centralised and moving slowly towards a federation of states by being led by a few core Member States. The EU can potentially become the United States of Europe with features similar to the former Soviet Union. Some Eurosceptical statements categorically express concern that joining the fiscal pact and adding amendments to the constitutions mean consequently giving up an ability to decide matters on Estonian state thus posing a threat to maintaining a sovereign nation state and "should again start to pay attention to strengthening sovereignty and guaranteeing constitutional rights of the citizens. It's time to restrict the supremacy of EU law that is proliferating in the Estonian legal system." (Raig \& Selge, 2012)

\section{Discussion}

Overall, the main arguments and concepts in the European discourse of Estonia are not much changed over the course of the last twenty years. The EU is primarily seen as a political and economic entity that guarantees support for the national project in achieving the nation state's goals. In fact, in times of economic crisis, the membership is even more valued. It is not surprising that the geopolitical and modernisation arguments are still predominant in the Estonian discourse and the membership is not only seen as an opportunity but as an unavoidable necessity for a small nation state like Estonia. In addition, it can be seen that the argument of self-interest is recurrently linked to economic or security debates.

In some cases, there seems to be a lack of input of the citizens in "EU questions" as the political elite conducts negotiations with the EU, sometimes with little transparency. For instance, the amendments to the Constitution were approached with hesitation. On the other hand, the interests of the EU are prioritised even though a certain degree of sovereignty needs to be negotiated and compromised. There are too many benefits at stake; after all, the EU is perceived as a necessity and an unavoidable entity.

Values such as solidarity, responsibility and cooperation cannot be ignored in the current political discourse and these concepts require some clarification in the context of the EU. Inter-state solidarity within the EU can be understood in Durkeheimian term 'organic solidarity'. According to Durkheim (1873), in case of 'organic solidarity' members of the group feel obliged of helping each other since their fate is interdependent (Durkheim, 1873; 1997). Fernandes and Rubio (2012) have proposed two conceptual tools driving solidarity within the EU in 
relation to EMU: 'direct reciprocity' ("I help others so they will help me in the future") and "enlightened self-interest' ("I help others as ultimately it serves my self-interests") (Fernandes \& Rubio, 2012). When debating over adopting the ESM and/or subsidies both arguments seem to be represented either from the EU's or Estonia's position.

All in all, the Estonian EU discourse stands out for its pro-EU stances and not notably challenging the EU while the Czech discourse appears more outspokenly Eurosceptical. As of the first hypothesis, similarly to the Czech discourse, the membership is unavoidable for increasing the living standard and catching up with the more developed Western countries, thus the instrumental hypothesis is applicable in the Estonian context, too. However, while the issue of security is moderately touched upon in the Czech debates, it not only plays a crucial role in the Estonian EU discourse but also links to the sovereignty/identity argument making Estonian discourse unique in comparison.

In the debates, the EU is understood as a hindrance (centralised union) in which the EU is depicted as an ideological construction as well as an artificial unit (compromising with sovereignty). Nevertheless, giving up some part of sovereignty (joining the ESM) is depicted often as an inevitable step to be taken that Estonia should go along showing solidarity at times of crisis. This argument can be interpreted as a recurring concept of necessity of the EU in the Estonian discourse fitting into instrumental hypothesis.

The natural hypothesis which refers to the EU as a natural political unit that does not challenge the existence of the nation state is fairly absent in the Estonian discourse and a few existing articulations are not much elaborated. It can be speculated it is due to the idea that belonging to European community has become a natural part in the Estonian identity discourse. There are only a few references such as "Estonia is an inseparable part of Europe"; "us as the EU". Re-establishing bonds with Western-European culture and community was an elite rhetoric during the accession years (Noreen \& Sjörstedt, 2004) and similarly so in the Czech Republic which forms a basic argument of the natural hypothesis in its EU discourse.

Considering the four hypotheses proposed by Braun (2008; 2009), the following modifications should be made. The first hypothesis remains the same with the exception that the dimension of security is added. Thus, the EU is understood as to achieve progress, to catch up with more developed countries and provide security for the nation state. The hindrance hypothesis, which is also applicable, can in principle remain the same, however it has been far less explicitly articulated than 
in the Czech discourse. Similarly, the EU as an artificial unit needs no redefinition.

\section{Output- and input-oriented legitimacy}

Eriksen and Fossum (2004) consider the output-based strategy of legitimation not sufficient. Similarly, some authors have criticised that a democratic political system cannot achieve output-oriented legitimacy without some form of inputoriented legitimacy (Büchs, 2008; Höreth, 1999). The results of the current study indicate that the EU is legitimised based on performance in the Estonian discourse and is output-oriented (in the terms of Scharpf, 1999), thus confirm the hypothesis set above. The findings could be seen in line with the authors who argue that it is sufficient to derive legitimacy via output mechanisms (Majone, 2006). According to Eriksen and Fossum (2004), output legitimacy is not sufficient as it loses its value once the benefits are gained. The security and defence concern linked to the geopolitical one seems to prove that it is not necessarily true. Since it is crucial to maintain independence and enhance security for Estonia, the output-based legitimacy on the EU discourse will very likely prevail in the Estonian EU discourse unless the EU's position marginalises in world politics. That makes Estonia's case very interesting since most of the countries accessing the EU at the same time tended to focus first and foremost on economic gains (Rasmussen, 2004).

In regard of input-based legitimation which means engaging citizens in decisionmaking process it is not evident. Since the EU is depicted as supreme law, it seemingly blocks attempts for participation for citizens at least with the matters of EU law. Furthermore, the Estonian elite seems to have little transparency in its decision-making process, leaving the people little voice. According to Eriksen and Fossum (2004), the input legitimation requires some common collective identity and values. The need of having solidarity towards other Member States and the EU, stressed in the Estonian discourse, can be seen as a value for a basis for a "we" feeling and the nation state's identification with the EU. At the same time, it is not clear whether it can necessarily be interpreted into formulation of European identity. Some authors claim that the development of a collective European identity is doubtful amongst citizens in Estonia (Berg, 2007; Pryce, 2011). However, according to the European Parliament Eurobarometer, 68 per cent of Estonians estimate their nationality to be more European compared to ten years ago and 46 per cent see themselves only European in the near future (Eurobarometer, 2013).

It can be summarised that the output legitimacy is not only prevalent in the 
Estonian EU discourse but the input legitimacy seems to play an insignificant role. The political and public discourse aims to convince its audience that the $\mathrm{EU}$ is a continuously functioning and useful union for the Estonian nation state whereas the citizens' participation-access to the decision-making processes (input legitimacy) — plays a seemingly irrelevant role.

\section{Conclusion}

In this study, European unity was analysed on the modernisation-sovereignty nexus via four different hypotheses of the EU (instrumental, hindrance, artificial, and natural) proposed by Braun $(2008 ; 2009)$. The paper demonstrated that all the theoretical hypotheses but natural hypothesis were applicable to the Estonian EU discourse. In regard of the modernisation argument that relates to the instrumental hypothesis, it proved necessary to add a security argument with an equal importance. Despite the economic crisis which has further undermined democratic legitimation in the EU, the country in the study is legitimised via output mechanisms whereas input legitimacy is regarding far less important. The study suggests that the EU is viewed as a necessity and unavoidable and the EU can be understood primarily as an instrument for achieving nationally set goals, first and foremost including security and economic growth. The public discourse reflects the concern on the stability and effective functioning of the EU in a future prospect. In line with Braun $(2008 ; 2009)$ it can be concluded that "the union that is conceived as failing to deliver progress loses its raison d'être" (Braun, 2009, p. 415). Lastly, it would be interesting to conduct a similar study on other Baltic states which share similar geopolitical and historical characteristics with Estonia.

\footnotetext{
Katri Vaaks holds a bachelor's degree in Sociology and Psychology from the Edinburgh Napier University, UK (2010). She has also studied at the University of Tartu in Estonia. She held a post of a research assistant and an independent researcher during her traineeship at the Institute of International Relations in Prague from October 2011 until August 2012 and cooperated in a research project on management and consulting at the Technical University of Chemnitz (2011). She is primarily interested in political sociology and issues related to it such as nationalism, ethnic conflict and ethnic minority groups. Currently she works as a freelancer in Prague.
} 


\section{References}

'Ansipi majandusime...' (2012), ‘Ansipi majandusime õitseb tänu eurorahale' [Ansip’s economic miracle blossoms with EU subsidies], Eesti Päevaleht, 12 Jan 2012.

Beetham, D. \& Lord, C. (1998), Legitimacy and the European Union, London \& New York: Longman.

Berg, E. (2007), 'Where East Meets the West? Baltic States in Search of New Identity,' in T. Hayashi \& H. Fukuda (eds.) Regions in Central and Eastern Europe: Past and Present, Sapporo: Slavonic Research Centre, pp. 49-67.

Braun, M. (2008), 'Talking Europe the Dilemma of Sovereignty and Modernization,' Cooperation and Conflict, vol. 43, no. 4, pp. 397-420.

- (2009), Modernisation Unchallenged: The Czech Discourse on European Unity, Prague: Institute of International Relations.

Baetens, M. \& Bursens, P. (2004), Mass Media Coverage and the reduction of the legitimacy deficit in the EU: The Belgian Case, Antwerpen: University of Antwerpen.

Büchs, M. (2008), 'How Legitimate is the Open Method of Co-ordination?' JCMS: Journal of Common Market Studies, vol. 46, no. 4, pp. 765-786. http://dx.doi.org/10.1111/j.1468-5965.2008.00804.x

Cerutti, F. (2008), 'Why political identity and legitimacy matter in the European Union,' in F. Cerutti \& S. Lucarelli (eds.) The Search for a European Identity: Values, policies and legitimacy of the European Union, London \& New York: Routledge, pp. 3-22.

Coicaud, J.-M. (2002), Legitimacy and Politics: A Contribution to the Study of Political Right and Political Responsibility, Cambridge: Cambridge University Press. http://dx.doi.org/10.1017/CBO9780511490200

Crombez, C. (2003), 'The Democratic Deficit of the European Union: Much Ado about Nothing?' European Union Politics, vol. 4, no. 1, pp. 101-120. http://dx.doi.org/10.1177/1465116503004001583

Diez, T. (2001), 'Europe as a Discursive Battleground: Discourse Analysis and European Integration Studies,' Cooperation and Conflict, vol. 36, no. 1, pp. 5-38. http://dx.doi.org/10.1177/00108360121962245

Dobson, L. \& Weale, A. (2003), 'Governance and Legitimacy,' in E. Bomberg \& A. Stubb (eds.) The European Union: How Does it Work? Oxford: Oxford University Press.

Drulak, P. (2001), 'The Return of Identity to European Politics,' in P. Drulak (ed.) National and European Identities in EU Enlargement: Views from Central and Eastern Europe, Prague: Institute of International Relations, pp. 1-20.

Durkheim, E. (1997[1893]), The Division of Labor in Society, New York: Free Press.

Ehin, P. (2006), 'Estonia and the crisis of European construction,' in A. Kasekamp (ed.) The Estonian Foreign Policy Yearbook 2006, Tallinn: Eesti Välispoliitika Instituut, pp. 9-29. 
Eurobarometer (2011), Public opinion in the European Union. European Commission. Eurobarometer Report, 75, Retrieved from http://ec.europa.eu/public_opinion/ archives/eb/eb75/eb75_publ_en.pdf

_ (2013), One year to go until the 2014 European elections: Analytical overview, EB79.5. European Parliament Eurobarometer Report. Retrieved from http://www. europarl.europa.eu/pdf/eurobarometre/2013/election/synth_finale_en.pdf

Fernandes, S. \& Rubio, E. (2012), Solidarity within the Eurozone: how much, what for, for how long? Project 'A test for European solidarity', Policy Paper, no. 51, Paris: Notre Europe.

Eriksen, E. O. \& Fossum, J. E. (2004), 'Europe in Search of Legitimacy: Strategies of Legitimation Assessed,' International Political Science Review, vol. 25, no. 4, pp. $435-459$.

http://dx.doi.org/10.1177/0192512104045089

Foucault, M. (1972), The Archaeology of Knowledge, Transl. by A. M. Sheridan Smith, New York: Pantheon Books.

Føllesdal, A. (2006), 'Survey Article: The Legitimacy Deficits of the European Union,' Journal of Political Philosophy, vol. 14, no. 4, pp. 441-468.

http://dx.doi.org/10.1111/j.1467-9760.2006.00244.x

Føllesdal, A. \& Hix, S. (2006), 'Why There is a Democratic Deficit in the EU: A Response to Majone and Moravcsik,' JCMS: Journal of Common Market Studies, vol. 44, no. 3, pp. 533-562.

http://dx.doi.org/10.1111/j.1468-5965.2006.00650.x

Hanso, H. (2011), 'Eesti võiks vabalt kaaluda mõnes ELi riigis saatkondi sulgeda,' [Estonia should consider closing embassies in some EU countries] Eesti Päevaleht, 8 Nov 2011.

Howorth, J. (2009), 'The Case for an EU Grand Strategy,' in S. Biscop, J. Howorth \& B. Giegerich (eds.) Europe: A Time for Strategy, Egmont Paper, Brussels: Egmont - The Royal Institute for International Relations, no. 27, pp. 15-24.

Höreth, M. (1999), 'No way out for the beast? The unsolved legitimacy problem of European governance,' Journal of European Public Policy, vol. 6, no. 2, pp. 249-268. http://dx.doi.org/10.1080/135017699343702

Ilves, T. H. (1999), 'EL laienemine ja Eesti identiteet rahvusvahelisel areenil,' [EU Enlargement and Estonian identity on the international arena] in Eesti ja Euroopa Liit: Eesti teel muutuvasse Euroopasse, Materials of International Conference 'Estonia and the European Union'. 3-5.11. 1999. Tallinn: Riigikantselei, pp. 60-64.

Kaljuvee, A. (2010), 'Juhtkiri: Samm Euroopa poole,' [A step towards Europe] Eesti Päevaleht, 18 Jun 2010.

Kirch, A. (2002), 'Eesti avalik arvamus Euroopa Liiduga liitumisest: heaolu on domineeriv tegur,' [Public opinion in Estonia towards EU accession: welfare as a dominant factor] Riigikogu Toimetised, no. 6, pp. 148-156. 
- (2007), Eesti teel Euroopa Liitu: kuidas on toimunud euroopastumine [Estonia on the road to EU: the Europeanization process]. Retrieved from http://www.ies.ee/ epub2007/akirch_etf6009.pdf

Kirch, A.; Brökling, I. \& Kivimäe, M. (2001), 'Images of Europe: The country study Estonia,' The Countries of Central and Eastern Eorope and the EU: Attitudes and Perceptions. Special edition of Social Science in Eastern Europe, pp. 70-82.

Kirch, A. \& Kirch, M. (2001), 'National and European Identities: the View from Estonia,' in P. Drulak (ed.) National and European Identities in EU Enlargement: Views from Central and Eastern Europe, Prague: Institute of International Relations, pp. 129-144.

Kirch, A.; Kirch, M.; Ruutsoo, R. \& Tuisk, T. (1998), ‘Jätkuv eurohuvi: võrdlusandmed uuringutest,' [Continued interest in EU accession: comparative studies] in A. Kirch \& R. Ruutsoo (eds.) Eesti Euroopa lävepakul, Tallinn: Teaduste Akadeemia Kirjastus, pp. 57-99.

Kirch, A.; Palm, T. \& Oole, K. (2002), 'Changes in EU-consciousness in Estonia 19952002: discussion and public opinion,' in A. Kirch \& J. Sillaste (eds.) Monitoring Preparations of Transition Countries for EU-Accession, Tallinn: Institute for European Studies, pp. 156-169.

Kuus, M. (2002a), 'European Integration in Identity Narratives in Estonia: A Quest for Security,' Journal of Peace Research, vol. 39, no.1, pp. 91-108. http://dx.doi.org/10.1177/0022343302039001005

_ (2002b), 'Sovereignty for Security? The Discourse of Sovereignty in Estonia,' Political Geography, vol. 21, no. 3, pp. 393-412.

http://dx.doi.org/10.1016/S0962-6298(01)00050-6

Lacroix, J. \& Nicolaïdis, K., eds. (2010), European Stories. Intellectual Debates on Europe in National Contexts, Oxford: Oxford University Press.

Lobjakas, A. (2011a), 'Nahk turule,' Postimees, 30 Sep 2011. (2011b), 'Sead lendavad,' Postimees, 3 Nov 2011.

Lord, C. \& Magnette, P. (2004), 'E Pluribus Unum: Creative Disagreement about the Legitimacy in the EU,' Journal of Common Market Studies, vol. 42, pp. 183-202.

Majone, G. (1996), 'Regulatory Legitimacy,' in G. Majone (ed.) Regulating Europe. London \& New York: Routledge, pp. 284-301.

http://dx.doi.org/10.4324/9780203439197

(1998), "Europe's 'Democratic Deficit': The Question of Standards," European Law Journal, vol. 4, no. 1, pp. 5-28.

http://dx.doi.org/10.1111/1468-0386.00040

(2006), 'The common sense of European integration,' Journal of European Public Policy, vol. 13, no. 5, pp. 607-626.

http://dx.doi.org/10.1080/13501760600808212 
Menon, A. \& Weatherill, S. (2008), 'Transnational Legitimacy in a Globalising World: How the European Union Rescues its States,' West European Politics, vol. 31, no. 3, pp. 397-416. http://dx.doi.org/10.1080/01402380801939610

Marquand, D. (2011), The End of the West: The Once and Future Europe, Princeton: Princeton University Press.

Moravcsik, A. (2002), “In Defence of the 'Democratic Deficit': Reassessing Legitimacy in the European Union," JCMS: Journal of Common Market Studies, vol. 40, no. 4, pp. 603-624. http://dx.doi.org/10.1111/1468-5965.00390

Noreen, E. \& Sjörstedt, R. (2004), 'Estonian Identity Formations and Threat Framing in the Post-Cold War Era,' Journal of Peace Research, vol. 41, no. 6, pp. 733-750. http://dx.doi.org/10.1177/0022343304047435

Olausson, U. (2010), 'Towards a European identity? The news media and the case of climate change,' European Journal of Communication, vol. 25, no. 2, pp. 138-152. http://dx.doi.org/10.1177/0267323110363652

Palk, P. (1999), Estonia and European Union. In: Estonian Human Development Report. Tallinn: Prisma Print, pp. 22-26.

Pryce, P. (2011), 'The civic solution to the Estonian identity crisis,' The Romanian Review of European Governance Studies, vol. 3, no. 6, pp. 5-22.

Raig, I. \& Selge, I. (2012), 'Euroopa Stabiilsusmehhanism on Eestile ohuks,' [European Stability Mechanism a danger to Estonia] Postimees, 8 May 2012.

Raik, K. (2000), 'What kind of Democracy, Whose Integration? Construction of Democracy and Integration into the EU of Estonia,' FIIA (UPI) Working Papers, no. 22, Helsinki: The Finnish Institute of International Affairs.

Rasmussen, S. B. (2004), 'Estonian Security Perceptions in the Context of EU Enlargement: A Critical Discussion,' Baltic Defence Review, no. 11, pp. 154-173.

Raudsaar, M. (1995), 'Eestist ja Euroopa Liidust,' [Of Estonia and the EU] Akadeemia, no. 3, pp. $478-448$.

Runnel, P. (2003), "Estonia's post-communist turn to Europe: the media and personal experience,' in B. Voicu \& H. Rusu (eds.) Globalisation, Integration and Social Development in Central and Eastern Europe, Sibiu: Psihomedia Publishing House, pp. 37-52.

Ruutsoo, R. (1995), 'Introduction: Estonia on the border of two civilizations,' Nationalities Papers: The Journal of Nationalism and Ethnicity, Special Issue Visions and Policies: Estonia's Path to Independence, vol. 23, no. 1, pp. 13-16. (1998), 'Euroopa Liit ja Eesti julgeolek,' [EU and Estonia's security] in R. Ruutsoo \& A. Kirch (eds.) Eesti Euroopa Liidu lävepakul, Tallinn: Teaduste Akadeemia kirjastus, pp. 9-22. 
Ruutsoo, R. \& Kirch, A. (1998), “Attitudes of Estonia's Population Towards Estonia's Accession to the European Union," Chapter 4: Integrating into Europe and the World, Estonian Human Development Report, pp. 76-82.

Scharpf, F. W. (1999), Governing in Europe: Effective and Democratic, Oxford: Oxford University Press. http://dx.doi.org/10.1093/acprof:oso/9780198295457.001.0001

Schwarzer, D. \& Youngs, R. (2013), Crisis in the Euro Area and Challenges for the European Union's Democratic Legitimacy, The EuroFuture Project, Paper Series, Washington, D.C.: The German Marshall Fund of the United States.

Sjursen, H. (2002), "Why expand? The question of legitimacy and justification in the EU's enlargement policy," Journal of Common Market Studies, vol. 40, no. 3, pp. 491-513.

http://dx.doi.org/10.1111/1468-5965.00366

(2008), Enlargement in Perspective: The EU's Quest for Identity, Arena Working Papers, no. 5, pp. 4-6.

Schmidt, V.A. (2010), The European Union in search of political identity and legitimacy: Is more Politics the Answer? Working Paper of the Vienna Institute for European Integration Research, no. 5, pp. 1-36.

Talts, M. (2000), 'Eurodebatist Eesti meedias: probleemid ja osalejad,' [On Eurodebate in the Estonian media: problems and participants] Riigikogu Toimetised, vol. 2, Tallinn: Riigikogu Kantselei, pp. 151-162.

Talts, M. \& Kirch, A. (1998), 'Estonia and the EU: pro and contra in the Estonian media,' in A. Kirch \& R. Ruutsoo (eds.) Eesti Euroopa Liidu lävepakul, Tallinn: Teaduste Akadeemia Kirjastus, pp. 100-113.

Vetik, R. (2001), Euroopa Liit ja Eesti avalik arvamus, Tartu: Tartu Ülikooli Kirjastus.

— (2003), 'Elite vs People? Eurosceptic Public Opinion in Estonia,' Cambridge Review of International Affairs, vol. 16, no. 2, pp. 257-271. http://dx.doi.org/10.1080/09557570302046

Waever, O. (2004), 'Discursive approaches,' in A. Wiener \& T. Diez (eds.) European Integration Theory, Oxford: Oxford University Press, pp. 197-215.

Wimmel, A. (2009), 'Theorizing the Legitimacy of European Governance: A Labyrinth with No Exit?' Journal of European Integration, vol. 31, no. 2, pp. 181-199. http://dx.doi.org/10.1080/07036330802642763 